\title{
Utilization of Geopark Medium for Resource Based Learning in Social Science to Improve Motivation and Learning Activity of Junior High School Students
}

\author{
Dadang Is Harimbo ${ }^{1}$, Yunastiti Purwaningsih ${ }^{1}$, Dewi Kusuma Wardani ${ }^{1}$ \\ ${ }^{1}$ Faculty of Teacher Training and Education Sebelas Maret University Surakarta \\ Corresponding e-mail: isdadang15@yahoo.co.id
}

\begin{abstract}
Resource-Based Learning approach by utilizing geopark medium in Grade VII of State Junior High School in Bulukerto Subdistrict make students more active, easy to understand the material presented by the teacher and motivate the students to not experience the saturation of learning. Geopark medium is a natural resource of the earth, used for education, geo conservation in particular, activities with students held in the classroom. Some of these geoparks are used to transfer information for schoolchildren and teachers, seminars and lectures. Media geopark type karst and springs in the cave used in learning geography in social science. The purpose of making this scientific paper is to know the use of geopark media on the learning process of social studies subjects in grade VII in SMP Negeri in District Bulukerto Wonogiri regency year 2016/2017. This research is action research cycles with procedure consisting of pre-action stage and cycle design I and cycle II, in which there is observation to know the motivation and activity of student study of data collection using observation, questionnaire, field note, interview, and documentation. Indicator of achievement result of $75 \%$ all students have reached research objectives. Test the validity of qualitative research data using triangulation. The result of data analysis was obtained by the result of the students' motivation improvement on the initial action of the average percentage 19\% from all students of class VII to $76 \%$ from the number of students of class VII that meet the criteria, after the action in cycle I and cycle II, Motivation of $90 \%$ of the number of students of class VII who meet the criteria mastery. Improved results on the aspect of motivation exceeded the planned target. Improvement of student learning activeness is seen from the change from result of action of cycle I which has been there improvement. Furthermore, after the second cycle of action occurs increased student activeness and beyond the planned target. In the pre-action, the learner activity only reached $21 \%$, then the cycle I increased to $77 \%$, continued to cycle II with the results of the first meeting the average learning activity $80 \%$ of the number of students in grade VII and increased in the second meeting the average learning activity $89 \%$ of the number of Grade VII students who have fulfilled the criteria of mastery.
\end{abstract}

\section{Keywords: Geopark Medium; Resource Based Learning; Motivation; Activity Learning.}




\section{BACKGROUND}

There are 3 State Junior High School (SMP) in Bulukerto District Wonogiri. The three SMP Negeri are SMP Negeri 1 Bulukerto, SMP Negeri 2 Bulukerto, and SMP Negeri 3 Bulukerto. The lesson is still using the Education Unit Level Curriculum (KTSP). The use of a new curriculum that is the 2013 curriculum will be conducted in the academic year 2017/2018. Implementation of Education Unit Level Curriculum (KTSP) demands that each student has the potential to be developed, so a suitable learning process is one that explores the potential of students to always be creative and develop so as to create a meaningful learning that will bring students to an impressive experience. The experience obtained by students will be more memorable if the learning process, students experience and do it yourself [1]. Creative learning will create an enjoyable state for students during the learning process by involving students actively improving students' understanding of the material and thinking abilities. Subjects that require active student involvement are Social Science (IPS). Based on the fact that there is in the field that IPS material requires a high understanding. This is why IPS lessons become less attractive, boring, so the motivation and activeness to learn less satisfactory. Student motivation and activeness in school cannot be separated from the role of educator.

Meaningful learning will bring students to a memorable learning experience. The experience that students get will be more memorable if the learning process obtained is the result of his own understanding and discovery. The ongoing learning process involves the students completely to formulate their own concept. The involvement of educators only as facilitators and moderators in the learning process. One of the efforts to create a quality learning process is to use active learning where students do most of their learning work. One of the active learning approaches is learning various resources (resource based learning) [1].

The curriculum is a number of subjects that must be taken by students to gain some knowledge [2]. Subjects are viewed as experiences of parents or clever people of the past, which have been systematically and logically arranged. These subjects fill the subject matter that is presented to the students, thus obtaining some useful knowledge for him. The more experience and discoveries, the more subjects that should be arranged in the curriculum and should be learned by the students at home. Preparing students in facing curriculum changes that emphasize the basic skills that must be possessed by graduates of an educational level, it is necessary for a teacher to provide maximum provision to learners including skills and life skills (life skills). For that while attending classes in class, all students are expected to be active in the learning process. Lessons that tend to use textbooks as well as lecture methods are conventional methods, indeed tend to be abstract and less related to daily life, so the concepts of subject matter are less well understood by students. Students are seen as organisms that have the potential to develop. The task of educators is to guide and provide conditions so that students can develop their talents and potential. In this case, children are active, do, and must be active themselves. The low motivation and the activeness of class VII students in SMP Negeri in Bulukerto sub district in social studies subjects are seen from the data obtained, there are still 90 students who have not fulfilled the Minimum Exhaustiveness Criteria (KKM). This value is obtained from the data of teachers who still apply the method of Teacher Centred Learning. Starting from that point, the teacher made a change of method from Teacher Centred Learning to Resource-Based Learning method. 
The purpose of the Resource-Based Learning method is to educate students to be selflearning and self-exploring, so they must be trained to deal with issues open to answers that must be explored, based on data collected from various sources, such as from Library research, laboratory experiments, and earth parks (geopark). Resource-Based Learning approach with geopark media in Grade VII of State Junior High School in Bulukerto Sub district is expected that students will be more active, easy to understand the material presented by the teacher and motivation.

\section{Literature}

The meaning of the media by Smaldino et al (2005: 9) can mean that the media is the communication and the source of information, taken from the Latin meaning between, this term refers to all things appropriate that bring information between the source and the recipient, for example including video, Diagrams, written materials, computer programs, and instructors). Educational media is a tool, method, and techniques used in order to further streamline communication and interaction between teachers and students in the process of education and teaching in the School [7]. Gerald and Ely (2004: 12) put forward three media traits which are clues to why media are used in learning, which the media can do in helping a teacher explain or explain a subject matter. The characteristics are: 1). Fixative properties (fixative property). This feature describes the media's ability to record, store, preserve, and reconstruct an event or object. An event or object can be ordered and arranged systematically and chronologically through media such as photography, video tape, audio tape, computer disks, and movies. An object that has been captured (recorded) using a camera or video camera can be reproduced (recreated) easily whenever needed. With this fixative feature, the media allows a recording of events or objects occurring at a certain time to be transported regardless of time, since it has been immortalized through the recording. 2). Manipulative properties (manipulative property). Changing an event or object is possible because the media has a manipulative feature. Events that take days to day can be presented back to learners in a short time with shooting techniques. For example, how to process the larvae into a cocoon and then into a butterfly (butterfly metamorphosis) can be accelerated by photographic techniques. Besides accelerating an event, an event may also be slowed down when recording the results of a video recording, utilizing existing facilities on the video. For example chemical reactions or to know the truth of the occurrence of violations in a soccer game can be observed through the aid of the manipulative ability of the media. Similarly, an action or a movement can be recorded with a camera photo to be observed or simply viewed.3).

\section{Distributive Properties}

Distributive features of the media allow an object or information to be transformed through the room and simultaneously presented to learners. Nowadays media distribution is not limited to one class only, or in one school scope only, but learning media such as cassette recording, video, or computer disk can be distributed wherever appropriate as needed. Because such media are practical medium with light weight and the size is also not large, so there is convenience to distribute it to remote areas though, there live or not support equipment used to operate the media. 


\section{Geopark}

According to UNESCO geopark is an area that has outstanding geological elements, including the archaeological, ecological and cultural values in it, where local communities are invited to participate in protecting and enhancing inheritance functions natural [2]. According to UNESCO's explanation, the main element in Geopark is divided into 3 elements namely Geodiversity, Biodiversity and Cultural diversity. The Global Geoparks, or Geopark Dunia (Geopark World) is a geological heritages or heritage site that has high ecological and cultural heritages and functions as a conservation, educational and sustainable development area. Geopark is a concept of sustainable development applied to an area where there is an internationally important geoheritage. Forms of media as a geopark of which is the area of Mount Sewu which is one of the most special karst area on the island of Java. The conical hills with around 40,000 karst hills have an area of up to 85 kilometres. The limestone depth at Mount Sewu reaches 1,300 square kilometres. Located along the southern coast of Yogyakarta Special Region, Central Java (Wonogiri), to East Java (Pacitan). Mount Sewu was formed when the limestone was lifted from the seabed about 1.8 million years ago. This area became part of human culture (inhabited by humans), since about 180,000 years ago, with evidence of settlements along the banks of the river and in limestone rocks shelters and caves on Mount Sewu. According to the Minister of Energy and Mineral Resources Regulation Number 17 of 2012, the karst landscape area showing exokarst and endokarst has the following criteria:

1) Has a scientific function as an object of research and investigation for the development of science

2) Has a function as an area of groundwater affixes that can be a medium to absorb surface water into the soil.

3) Has a function as a groundwater storage media permanently (permanent) in the form of aquifers sufficient presence of hydrological functions.

4) Have permanent springs, and

5) Has a cave that forms a river or underground river network

According to the Regulation of the Minister of Energy and Mineral Resources Number 17 of 2012, as for the forms of exokarst referred to above are: permanent springs, karst hill, Dolina, Uvala, Polje, Lake Motivation to learn Sardiman (2008: 75) defines motivation as the overall driving force within the self that leads to learning activities, which ensures the continuity of the learning activities and which gives direction to the learning activities, so that the desired objectives by the subject of learning can be achieved. Motivation to learn is a process that encourages learning, direction, and persistence of behaviour. That is, motivated behaviour is a behaviour that is full of energy, directed and lasting long. Winkel (1983: 270) defines that "Learning motivation is the overall driving force within the student that engenders activity and gives direction to learning activities". Based on the above understanding can be taken the sense that the motivation to learn is a boost or driving force from within the individual that gives direction and passion for learning activities, so as to achieve the desired goal. Motivation will enhance, strengthen and direct the learning process, so that will be obtained effectiveness in learning. The function of motivation according to Sardiman (2008: 85) are:

1. Encourage people to act, so as a mover or a motor that releases energy. 
2. Determining the direction of action, i.e. toward the goal to be achieved. 3. Selecting the act, which determines which actions should be done harmoniously to achieve the goal by setting aside actions that are not beneficial to that goal.

Further Uno (2008: 17) explains that the function of motivation in learning: Encouraging people to perform an activity based on the fulfillment of needs, determining the direction of goals to be achieved, and determining the actions to be done. Supriyadi (2005: 86), argues that student learning motivation can be observed from several aspects, namely: attention to the material, diligence in learning, interest in learning, the frequency of learning, commitment in fulfilling school tasks, the spirit of learning and the presence of students in school. Sardiman (2008: 83) suggests the characteristics of people who are motivated are: Diligent to face the task, Dullness facing difficulties, Showing interest in various problems, Preferably working independently, Quickly bored on routine tasks, Can defend his opinion, Not easy Letting go of the thing it believes, Happy solving the problem.

\section{Activity Learning}

Activity is an activity that is physical and mental, that is, do and think as a series that cannot be separated (Sardiman, 2001: 98). Successful learning must go through a variety of activities, both physical and psychological activities. Physical activity is an active enterprising student with limbs, making something, playing or working, not just sitting and listening, seeing or just being passive. Students who have psychic activity (psychological) is if the power of his soul work as much or much work in the framework of learning. Rousseau in Sardiman (1986: 95) states that everyone who learns must be active alone, without any learning process activity will not happen. Thorndike (1987: 82) suggests the learning activity of students in learning by law "law of exercise" it states that learning requires the existence of exercises. Mc Keachie states with regard to the principle of liveliness that the individual is "an active learning human being always wants to know" [15]. All knowledge must be gained by self-observation, self-experience, self-inquiry, by self-employment with self-created facilities, spiritually and technically. Based on the opinion can be concluded that the activity of students in learning is all activities that are physical and non-physical students in the process of teaching and learning activities are optimal so as to create a class atmosphere to be conducive. The types of student activities in learning are as follows (Sardiman, 1988: 99): Visual activities, including reading, watching demonstrations, experiments, other people's work, Oral activities, such as: stating, formulating, asking, , Exchanging opinions, conducting interviews, discussions, Listening activities, for example listening: conversations, discussions, music, speeches, Writing activities, such as writing stories, essays, reports, questionnaires, copying, Drawing activities e.g. drawing, graphs, Diagrams Motor activities, including: experimenting, constructing, playing, Mental activities, for example: responding, remembering, solving problems, analyzing, making decisions, Emotional activities, such as: interest, boredom, Excited, passionate, calm.

\section{Resource-Based Learning (RBL)}

According to Dorrell (2009: 233) suggests that the use of various sources of learning is the driving force for the development of open learning systems, distance 
learning and flexible learning, so that the term learning based on various sources is actually included in it. Brown \& Smith in Siregar (2009: 312) suggests that actually learning a variety of sources is not something new because students have long used learning resources such as books, then increased use of the media including open study materials, study instructions, textbook instructions, books work, video and audio packages. Due to technological developments, it is possible to use sophisticated media.

\section{RESEARCH METHODS}

This study is an Action Research in several schools (School Wide Research) which is implemented in 2 cycles. Each cycle is carried out in four stages: (1) action planning, (2) action implementation, (3) observation and interpretation, and (4) analysis and reflection of action. Methods of data collection used by using observation, field notes, interviews, and documentation. This research procedure consists of several stages: action planning, cycle design, action implementation, observation and interpretation, analysis and reflection of action. In order for the results of research can be justified truth, then researchers use triangulation techniques. By reducing the data, summarizing or brief description of field notes, observation data, plus supporting data of the interview results and then presenting the data done in order to compile the systemic information from the data reduction results then a conclusion withdrawal which is the final stage in data analysis. The collected data is presented systematically and needs to be given meaning. Success Criteria a class action is said to succeed if the action reaches the specified criteria. Zaenal Aqib (2009: 41) states that the criteria of success with the standard of $75 \%$ of the expected number is already high.

\section{DISCUSSION}

After learning activities apply resource-based learning model by utilizing geopark media, there is an increase of students' learning motivation and activeness. Improvement of student's learning motivation and activity from cycle I and cycle II can be seen from the statement as follows: Aspect Tekun, the cycle I reached 74\%, then in the second cycle increased to $97 \%$. Aspects of Spirit and Ductile, in the first cycle reached $79 \%$, then in the second cycle increased to $96 \%$. Aspects of Interest and Attention, in the first cycle reached $78 \%$, then in the second cycle increased to $82 \%$. Aspects Happy to Work Alone, in the first cycle reached $75 \%$, then in the second cycle increased to $82 \%$. Visual activity, on the first cycle reached $74 \%$, then in cycle II increased to $90 \%$. Oral Activity, in the first cycle reached $80 \%$, then in cycle II increased to $96 \%$. Listening activity, in the first cycle reached $75 \%$, then in cycle II increased to $80 \%$. Writing activity, in the first cycle reached $78 \%$, then in cycle II increased to $86 \%$. Completeness of student learning outcomes in the first cycle to obtain grade average grade 79.84 with a percentage of $78.13 \%$, while in cycle II increases with grade average grade 85.84 with $90.63 \%$ percentage. The study was conducted in 2 cycles. Each cycle consists of four stages: (1) action planning, (2) action implementation, (3) observation and interpretation, and (4) analysis and reflection of action. Researchers before conducting the cycle I to observe to determine the conditions that exist in class VII in SMP Negeri Bulukerto District. From the in-depth observation, 
researchers found the motivation to study subjects IPS is still not maximized. Furthermore, after knowing the problems that arise, the researchers with subject teachers conduct discussions to be able to overcome these problems through the application of resource-based learning model by utilizing geopark media. Based on the observation of the learner activity on 4 aspects i.e. visual activity aspect, oral activity, listening activity, and writing activity has increased every cycle and has exceeded the expected indicator. The same thing is seen in the motivation to learn learners have increased each cycle and has exceeded the expected indicators. The observations found problems encountered in teaching and learning subjects IPS that can be resolved through the application of resource-based learning model by utilizing geopark media. To interpret the findings conducted interview toward learners and teachers subjects IPS after the research. The results of interviews conducted on learners is known that through the application of resource-based learning model by utilizing geopark media can increase learners become active in the learning process, to train students to find their own answers that come from the media directly, and learning more interesting and easily understood by learners in the learning process of social studies subjects. While the results of interviews conducted on IPS subjects teachers obtained information that through the application of learning resource-based learning model by utilizing geopark media can improve the motivation and learning activeness of learners on IPS subjects.

\section{REFERENCES}

[1] Hadiningtyas (2011). Penerapan Resource Based Learning Tersedia: <http://http://eprints.uny.ac.id> (accesed from 10 Desember 2016).

[2] Andriany, S, S. (2016). Geowisata Geopark Ciletuh. Science Contribution, 14 (1), 75-88.

[3] Arikunto. (2002). Dasar-Dasar Evaluasi Pendidikan. Jakarta: PT.Bumi Aksara

[4] Amelia (2016). Upaya Pemerintah Indonesia Menjadikan Gunungsewu Sebagai Global Geopark Network tahun 2013-2015. Skripsi

[5] Azman (2015). The Langkawi Global Geopark: local community's perspectives on public education.

[6] Barna, C. (2011). Eco tourism - Conservation of Natural and Cultural Heritage. Social Economic Research, 1 (1), 87-90.

[7] Butler, Max. (2012). Resource-Based Learning and course design Libbrecht. (2015). Adaptations to a Learning Resource. Acta Didactica Napocensia, 8 (1), 67-70.

[8] Chaeruman. (2008). Tips Melaksanakan Resources Based Learning. Accessed from http://projects.coe.uga.edu/epltt/index.phptitle=Resource-based_Learning.Pada tanggal 22 november 2016.

[9] Chang, S. H, (2007) Science across the world in a Resource Based Learning Activity regarding Sustainable Development Issues. Journal Science Education International, 18 (4), 245-254.

[10] Doiron, R. (1999) In formation Technology into Resource Based Learning. Journal Education Resource Information Centre, 30 (1), 145-148.

[11] Darmaja, I, M. (2016). Model Kemasan Wisata Batur Global Geopark. Journal IPTA, 4 (1), 2025.

[12] Darsiharjo. (2016). Pengembangan Geopark Ciletuh Berbasis Partisipasi Masyarakat. Jurnal Managemen Resort, 13 (1), 55-60.Sharina, A. H. (2011). Geopark as a Potential for Alleviating. The International Journal of Research into Island Cultures, 5 (1), 76-97.

[13] Diana, M. (2014). Langkawi Island the Carrying Capacity. Journal school of Housing, 12, 1-6. <http://http://emerald.journal> (diakses 24 Desember 2016)

[14] Depdiknas. (2005). Peraturan Pemerintah Nomor 19 Tahun 2005 Tentang Standar Nasional Pendidikan.

[15] Dimyanti \& Mudjiono. (2009). Belajar dan Pembelajaran. Jakarta. Rineka Cipta.

[16] Djaali \& Pudji Muljono. (2008). Pengukuran Dalam Bidang pendidikan. Jakarta. PT. Grasindo. 
[17] Eveline Siregar. (2009). Pengembangan Belajar Berbasis Aneka Sumber

[18] Greenhow, C. (2006) Methods for evaluating online, Resource-based Learning Environments for Teacher. Journal of Computing in Teacher Education, 23 (1), 21-23.

[19] Heather, F. (2007). Re-working Resource Based Learninga-case Study. Innovations in Education and Teaching International, 44 (1), 79-91.

[20] Henrique (2012). The Arouca Geopark (Portugal) as an educational resource. Available: <http://http://emerald.journal> (diakses 10 Desember 2016)

[21] Hannafin and Hill (2002). Resource Based Learning. <http://http://emerald.journal> (accesed from 10 Januari 2017)

[22] Kemmis, Stephen \& Mc. Taggart Robin. (1988). The Action Research Planner. Victoria: Deakim University

[23] Kononets, N. (2015). Experience in Implementing Resource Based Learning. Journal of Distance Education, 16 (2), 151-154. 